\title{
Dezerterzy przed sądami Drugiej Rzeczypospolitej
}

W latach 1921-1939 wojskowy wymiar sprawiedliwości ukarał kilka tysięcy żołnierzy, którzy dopuścili się dezercji. Tylko w 1924 roku Wojskowe Sądy Okręgowe (dalej: WSO) skazały za to przestępstwo 2261 żołnierzy, w tym 7 oficerów. Od stycznia do listopada 1925 roku orzeczono wyroki wobec 1956 dezerterów, w tym 3 oficerów. W latach 1930-1935 sądy wojskowe wymierzyły łączną karę 3818 żołnierzom ${ }^{1}$. Nie wszyscy zbiegli żołnierze zasiedli na ławie oskarżonych. Trzeba pamiętać, że wielu dezerterów z Wojska Polskiego (dalej: WP) przedostało się zagranicę i nigdy nie powróciło do kraju.

Celem artykułu jest przeanalizowanie procesów prowadzonych przeciwko aresztowanym dezerterom w WP w latach 20. i 30. XX wieku. Spośród kilkudziesięciu spraw, które prześledziłem w czasie naukowych kwerend, wybrałem różne przypadki. W artykule opisuję m.in. procesy dezerterów, którzy popełniali przestępstwa kryminalne, a także byli oskarżani o szpiegostwo. Bazując na zgromadzonych przedwojennych materiałach archiwalnych, a także na przedwojennej prasie, próbowałem uzyskać odpowiedź, jak przedwojenne sądy traktowały zbiegów z ówczesnego wojska. Jakie okoliczności wpływały na zasądzanie bardziej surowych, a jakie na łagodniejszych kar? W artykule ukazuję sylwetki niektórych adwokatów, którzy dość często bronili dezerterów. Interesowało mnie także, jakie argumenty stosowali oni broniąc dezerterów.

${ }^{1}$ P. Stawecki, Z badań nad dyscyplina, przestępczościa i moralnościa wojska Drugiej Rzeczypospolitej, Warszawa 2000, s. 13, 20. W czasie pokojowego funkcjonowania Drugiej Rzeczypospolitej duża liczba wyroków dotyczyła zbiegów, którzy dopuszczali się także kradzieży wojskowego mienia (dezerterzy uciekali z bronią, wojskowym oporządzeniem, często w umundurowaniu, które nie zawsze odzyskiwano). Dezerterów dobrowolnie powracających lub wydalanych z zagranicy oskarżano jeśli nie o szpiegostwo, to o udzielanie wyczerpujących informacji wojskowym wywiadom obcych państw. 
Już na początku rozprawy sądowej ważne było rozstrzygnięcie, czy oskarżonemu zarzuca się dezercję (długotrwałe porzucenie służby), czy też samowolne oddalenie się (krótkotrwałą nieobecność w wojsku). W pierwszej połowie lat 20. różnica pomiędzy „dezercją” a „samowolnym oddaleniem się” nie była czytelna. W różnych pułkach interpretowano tę kwestię zupełnie inaczej. Nie był to jedyny problem. Dowódcy jednostek WP w oficjalnych raportach podnosili zarzut, że termin „dezerter” nie został ściśle zdefiniowany ${ }^{2}$. W konsekwencji nawet po kilkunastu dniach nieobecności dowódcy wielu pułków nie uważali zbiegłych żołnierzy za dezerterów. Krótkotrwałe oddalenia dowództwo często zaś traktowało pobłażliwie. Niebezpieczeństwo masowego bagatelizowania w pułkach samowolnego oddalenia się zasygnalizował w końcu lat 20. Oddział II Sztabu Generalnego WP (dalej: O. II SGWP) ${ }^{3}$. Analitycy sztabu alarmowali, że nagminne lekceważenie tego zjawiska obniża poczucie wojskowej obowiązkowości i dyscypliny ${ }^{4}$.

10 kwietnia 1923 roku Ministerstwo Spraw Wojskowych (dalej: M.S.Wojsk.) wprowadziło w życie rozkaz nr 13, poz. 169 o postępowaniu w wypadkach dezercji. W opublikowanym rozporządzeniu za dezertera uznano każdego wojskowego, który opuścił oddział, stanowisko służbowe, wyznaczone miejsce pobytu lub nie powrócił $\mathrm{w}$ wyznaczonym terminie. W rozkazie $\mathrm{nr} 13$ dalej jednak nie ustalono granicy między „dezercją" a „samowolnym oddaleniem się"5. Sytuacja nie zmieniła się pod koniec lat 20. W rozkazie nr 32, pkt. 387 z 22 listopada 1927 roku M.S.Wojsk. dalej nie zdefiniowano, czym jest „samowolne oddalenie”, a czym ,dezercja”. Podobnie było w rozkazie nr 7 z 17 września 1934 roku M.S.Wojsk. W 1927 i 1934 roku pełniący obowiązki ministra spraw wojskowych Józef Piłsudski nakazywał jak najszersze zebranie informacji o zbiegu. Przełożeni mieli ustalić przyczyny i przypuszczalny kierunek ucieczki. Rozkaz z 1927 roku zobowiązywał do rozesłania jednej karty pościgowej do żandarmerii, a drugiej do policji; w 1934 roku już tylko do żandarmerii. W rozkazach nr 32 i nr 7 nakazywano dowódcy Oddziału Żandarmerii (dalej: OŻ) wysłanie karty pościgowej do prokuratora przy $\mathrm{WSO}^{6}$. Wysłanie kart pościgowych do prokuratora następowało po upływie 14 dni od nieuzasadnionej i nieusprawiedliwionej nieobecności.

${ }^{2}$ Wojskowe Biuro Historyczne (dalej: WBH) (byłe Centralne Archiwum Wojskowe), O. II SGWP, Meldunek ppłk. Leopolda Cechaka, dowódcy 3 Pułku Artylerii Polowej w Zamościu z 24.06.1924 r., sygn. I.303.4.2510, nlb.

${ }^{3}$ Od 1928 r. Sztabu Głównego WP.

${ }^{4} \mathrm{WBH}$, O. II SGWP, Komunikat informacyjny na podstawie danych statystycznych, stanu narodowościowego, dezercji, samouszkodzeń i szpiegostwa w wojsku (dane z lat 1926-1927), sygn. I. 303.4.2561., s. 21, nlb.

${ }^{5}$ Dz.Rozk.Wojsk. z 1923 nr 13 poz. 169.

${ }^{6}$ Dz.Rozk.Wojsk. z 1927 nr 32 poz. 387, Dz.Rozk.Wojsk. z 1934 nr 7 poz. 154. 
Przyjąć więc można, że 14 dni nieobecności w warunkach pokojowych oznaczało dezercję.

22 marca 1928 roku Prezydent Rzeczypospolitej Polskiej podpisał rozporządzenie w sprawie kodeksu karnego wojskowego, którego art. 50 zawarty w Dz.U. nr 36, poz. 328 uznawał, że za samowolną dezercję (to jest samowolne oddalenie się) przyjmuje się nieobecność trwającą dłużej niż 7 dni, a w warunkach polowych dhużej niż 3 dni. Za to przestępstwo groziła kara do 2 lat więzienia. Art. 53 tegoż rozporządzenia wskazywał, że trwałe uchylanie się żołnierza od służby wojskowej skutkuje uznaniem tego czynu za dezercję. W tymże rozporządzeniu zjawisko dezercji definiowały art. 54-62. Rozpiętość kar za to przestępstwo była dość znaczna. Od 6 miesięcy do 3 lat przy pierwszej dezercji, przy pierwszym powtórzeniu kara nie mogła być krótsza niż rok więzienia, przy następnym powtórzeniu kara ciężkiego więzienia do 10 lat . Ustawodawca przewidział również kary między innymi za dezercje zbiorowe i podżeganie do tego przestępstwa. Wprowadzenie w życie 1 sierpnia 1928 roku aktu z 22 marca 1928 roku wywołało ożywioną dyskusję wśród przedwojennych specjalistów zajmujących się prawem wojskowym. Jej świadectwem jest polemika na łamach „Wojskowego Przeglądu Prawniczego", prowadzona w latach 1928-1929. Szczególnie mocno spierano się, czy niestawiennictwo można łączyć z samowolnym oddaleniem się ${ }^{8}$. Niestety brak uściślenia przepisów Kodeksu Karnego Wojskowego (dalej: KKW) z 1928 roku nie dotyczył tylko niestawiennictwa. Różnie na przykład można było interpretować tzw. sformułowanie przestępstwa mniejszej wagi (art. 51, 52, 54), które obejmowało samowolne oddalenie się i dezercję. Pojawiające się mankamenty były w dużej mierze wynikiem tego, że konstruowanie nowych przepisów prawnych dla WP odbywało się na bazie obowiązujących od niedawna, trzech zupełnie odrębnych kodeksów wojskowych. Jak słusznie zauważył Adam Lityński, duży wpływ na unifikację prawa wojskowego mieli oficerowie Sztabu Generalnego, a nie wojskowych służb sprawiedliwości. Prace nad kodyfikacją wojskowego prawa w 1928 roku były intensywne, a także planowane jako przejściowe?

Określone kary za przestępstwa dezercji, jakie wprowadził KKW z 1928 roku, w większości zostały w latach 30. niezmienione. Podobne kary przewidywała ustawa KKW z 21 października 1932 roku. Przykładowo art. 46 par. 1, zakładał, że jeśli nieobecność w jednostce trwała ponad 6 miesięcy, to sprawca będzie podlegał

${ }^{7}$ Dz.U. z 1928 r. nr 36 poz. 328.

${ }^{8}$ W latach 1928-1929 na ten temat polemizowali m.in. kpt. Jan Adamus, mjr Stanisław Mitzner i mjr Karol Müller. Zob. Kpt. K.S. dr J. Adamus, Niestawiennictwo, „Wojskowy Przegląd Prawniczy” (dalej: WPP) 1928, nr 8-10, 10-12, s. 81. i Mjr K.S.K. Müller, W sprawie niestawiennictwa, WPP 1929, nr 7-8, s. 11.

9 A. Lityński, Dwa kodeksy Karne 1932. W osiemdziesiąta rocznice, , ,Roczniki Administracji i Prawa” R. XII, 2012, s. 215. 
karze do 10 lat więzienia. Jednak ustawodawca w 1932 roku wprowadził pewne zmiany. Po pierwsze, znikało rozróżnienie między „samowolnym oddaleniem się” i „dezercją”. Tego rodzaju przestępstwa określano już w art. 43 jako łamanie obowiązku wojskowego. Nie przewidywano, jak wcześniej, uzależniania kary od liczby dezercji. Wprowadzono także przepis, że jeśli zbiegły żołnierz powrócił dobrowolnie, a jego nieobecność nie przekroczyła 6 tygodni w przypadku pokoju, a w czasie wojny 7 dni, to sąd może zastosować nadzwyczajne złagodzenie kary (art. 49) ${ }^{10}$. KKW z 21 października 1932 roku obowiązywał do końca II RP.

W przedwojennej Polsce wiele skomplikowanych procesów o dezercję skończyło się pomyślnie dla oskarżonych. Zdarzało się to zwłaszcza, kiedy obrońcy wykazywali spore zaangażowanie, a także potrafili wykorzystywać nieprecyzyjne przepisy prawne. Do takich osób należał poznański adwokat płk dr Antoni Neusser, w latach 1923-1929 pełniący funkcję szefa miejscowego WSO nr VII. Potwierdzeniem jego umięjętności była obrona szer. Józefa Janika z 56 pp. Janik został zatrzymany 3 lutego 1934 roku w miejscowości Kowale Księże w powiecie tureckim. Przy próbie zatrzymania zbiegły żołnierz zastrzelił jednego z mieszkańców wsi, który pomagał w policyjnej obławie, a także ciężko ranił policjanta. Ukrywający się na terenie wioski Janik strzelał również do mieszkańców pomagającym policji w jego ujęciu ${ }^{11}$. Po bardzo krótkim procesie, 17 lutego 1934 roku szer. Janik został skazany na karę śmierci. Wyroku nigdy nie wykonano. Swoje życie zabójca i dezerter z 56 pp zawdzięczał płk. Neusserowi. Adwokat w piśmie do Naczelnego Prokuratora w Warszawie przypomniał dotychczasową niekaralność i bardzo dobrą opinię, jaką szer. Janik cieszył się w krotoszyńskim pp. Neusser napisał także, że dezerterowi zabójcy pozostało jedynie 8 dni do zakończenia służby wojskowej. Poznański adwokat dowodził, że do zbrodniczego czynu zbiegły żołnierz został namówiony przez inne osoby. Obrońca Janika przekonywał, że dezerter chciał oddać się w ręce żandarmerii, a właśnie interwencja policji, a także pomagających jej (co wcale nie było powszechne) ochotników z miejscowości Kowale Księże doprowadziła do niepożądanego rozwoju wydarzeń ${ }^{12}$. Płk Neusser napisał odręcznie w swoich notatkach, że prezydent państwa ułaskawił Janika. Mościcki zamienił wyrok kary śmierci na dożywotnie więzienie.

Płk Neusser bronił także dezerterów w innych skomplikowanych i trudnych sprawach. Był bardzo skuteczny. Na początku października 1933 roku argumentacja poznańskiego adwokata przyczyniła się do wymierzenia łagodnej kary strz. kon.

${ }^{10}$ Dz.U. z 1932 r. nr 91 poz. 765.

${ }_{11}$ Archiwum Państwowe w Poznaniu (dalej APP), Adwokat Neusser Antoni (dalej: ANA), Rozkaz stawienia przed sądem doraźnym, pismo gen. bryg. Oswalda Franka, dowódcy DOK nr VII, Poznań II 1934 r., sygn. 37, nlb., s. 1-2.

12 APP, ANA, Pismo płk dr A. Neussera do Naczelnego Prokuratora w Warszawie, [brak miejsca i daty], sygn. 37 , nlb. 
Maksymilianowi Łaptiukowi. Żołnierz z 7 Pułku Strzelców Konnych (dalej: PSK) ze Zbąszynia nie tylko zbiegł na kilka dni do Niemiec, ale miał również udzielić w tym kraju licznych informacji o WP, postawiono mu więc poważny zarzut szpiegostwa. Groziło mu nawet 10 lat więzienia o zaostrzonym rygorze. Ostatecznie 3 października 1933 roku WSO w Poznaniu Łaptiuka skazały jedynie na 1,5 roku więzienia ${ }^{13}$. Neusser wykazywał dużą skuteczność także w sprawach o szpiegostwo, kradzież, symulowanie chorób w czasie służby i propagowanie ideologii komunistycznej w wojsku. Swojej działalności nie prowadził charytatywnie. We wspomnianym procesie Łaptiuka honorarium Neussera było skromne i wyniosło 75 zł. Zazwyczaj jednak płk Neusser żądał za prowadzenie sprawy znacznie więcej. Stawki wynosiły 300-350 $\mathrm{z}^{14}$. Adwokat nigdy jednak nie gwarantował pomyślnego rozstrzygnięcia sprawy karnej. W wielu procesach płk. Neusserowi udawało się jednak doprowadzić do całkowitego uniewinnienia oskarżonego. Przykładem była rozprawa Edmunda Fränkla, strzelca 7 pp - żydowski żołnierz oskarżony o szerzenie w WP komunistycznej ideologii został uniewinniony ${ }^{15}$.

Płk Neusser bronił również polskich żołnierzy, którzy szukali w Niemczech azylu. Wielu dezerterom trudno było ułożyć sobie tam życie. Porzucali pracę, bezrobotni włóczyli się po Niemczech, często dopuszczając się różnych drobnych przestępstw. Po kilku latach sami powracali do ojczyzny albo wydalano ich z Niemiec. Po powrocie do Polski byli natychmiast aresztowani i skazywani na od roku do kilku lat więzienia. Poznański adwokat często argumentował, że na decyzję o dezercji wpływ miały niemieckie kobiety. Tak było w sporządzonym przez płk. Neussera 6 sierpnia 1936 roku odwołaniu do Najwyższego Sądu Wojskowego (dalej: NSW) w Warszawie. W piśmie obrońca odwoływał się od wyroku poznańskiego WSO, który 30 lipca 1936 roku skazał szer. Emila Trzaskalika z 16 pp za czteroletnią dezercję w Niemczech na 3 lata więzienia. Neusser wskazywał, że WSO w Poznaniu wymierzył szer. Trzaskalikowi zbyt surową karę, ponieważ „pominął sąd przy tym tą okoliczność, że te wszystkie okoliczności były tylko następstwem tego, iż oskarżony dał się uwieść do dezercji przez kochankę, Niemkę i obywatelkę niemiecką, i wobec tego nie mogą wykazywać tak wielkiego natężenia złej woli, iżby uzasadniały karę aż 3-letniego więzienia" ${ }^{16}$. Neusser w odwo-

13 APP, ANA, Notatki płk. dr. A. Neussera z 3.10.1933 r. dot. rozprawy strz. kon. Maksymiliana Łaptiuka, sygn. 31, nlb.

${ }^{14}$ Dla porównania warto zauważyć, że uposażenia polskich sędziów i prokuratorów w końcu lat 30. wynosiły od 425 do 1100 złotych. Zob. Mały Rocznik Statystyczny 1939, Warszawa 1939, s. 278.

15 APP, ANA, Notatki płk. Dr. A. Neussera z 14.12.1932 r. dot. rozprawy strz. ułan. Maksymiliana Łaptiuka, sygn. 29, nlb.

${ }^{16}$ APP, ANA, Sprawa karna strz. Trzaskalika Emila, odwołanie skierowane do NSW w Warszawie przez WSO nr VII w Poznaniu, pismo podpisane przez [płk.] dr. [Antoniego] Neussera, [Poznań], 06.08.1936 r., sygn. 38, s. 2, nlb. 
łaniu stanowczo podkreślał, że do dezercji przekonała żołnierza kochanka, która szantażowała go popełnieniem samobójstwa, gdyby odmówił.

Fatalną rolę kobiet, dla których zakochani żołnierze uciekali z wojska, podkreślała przedwojenna prasa. Jeden z takich dramatów rozegrał się na początku czerwca 1936 roku na krakowskich Skałkach Twardowskiego, opisały go „Ostatnie Wiadomości Krakowskie". Według znanej z sensacyjnych tematów gazety w tym miejscu z rewolweru zastrzelił się zbiegły z wojska pod koniec marca 1936 roku kpr. Eugeniusz Góralczyk. Jak podkreślono w artykule, broń, z której żołnierz popełnił samobójstwo, ukradła wraz z 800 złotymi jego 23-letnia kochanka Helena Kubrakiewicz, kierowniczka oddziału pocztowego w Kalinowie k. Sambora. Para przebywająca w kwietniu i maju 1936 roku w Krakowie miała prowadzić hulaszczy tryb życia, jak pisano, „szeroko zabawiała się w różnych lokalach" ${ }^{17}$. Problem pojawił się, kiedy skończyły się pieniądze.

Po zdobyciu prawa łaski dla Janika Neusser nabrał przekonania, że pisanie listów z prośbą o ułaskawienie do prezydenta Mościckiego może być bardzo skuteczne. Tę metodę poznański adwokat zastosował do weryfikacji zasądzonego wyroku kpr. Józefa Lei. Dezerter brał udział w wojnie polsko-bolszewickiej, od 13 lat przebywał w Niemczech, a potem we Francji. W 1933 roku wraz z żoną i czwórką dzieci powrócił do Polski i osiedlił się w Ostrowie Wielkopolskim. Jego rodzinne szczęście nie trwało zbyt długo. W grudniu 1934 roku aresztowano go, a 18 lutego 1935 za zbiegostwo z jesieni 1920 roku skazano na rok więzienia. Neusser pisząc w imieniu Lei prośbę o łaskę do prezydenta, kładł nacisk na przyjęcie przez skazanego odpowiedzialności za popełnione czyny, a jednocześnie wskazywał na dramatyczną sytuację rodzinną: „Najdostojniejszy Panie Prezydencie Rzeczypospolitej, nie ośmieliłbym się prosić o łaskę dla siebie, gdyż wyrok i karę przyjmuję jako zasłużoną i sprawiedliwą pokutę za mój zły czyn - ale proszę i błagam o łaskę dla tej nieszczęsnej mej sparaliżowanej żony i tych czworga małych niewinnych dziatek - które potrzebują mej pracy i zarobku oraz starania i pielęgnacji. Daruj mi Najdostojniejszy Panie Prezydencie z zasłużonej przeze mnie kary - jej resztę jeszcze nie odbytą, bym mógł pracować i dbać o moją nieszczęsną rodzinę"18. Neusser zalecił, aby napisany przez niego list został podpisany przez osadzonego. Jednym z bardziej znanych podoficerów, których przed zarzutami dezercji z urzędu bronił płk Neusser, był

${ }^{17}$ Kronika Krakowa. Kapral zastrzelit się na skałach Twardowskiego, „Ostatnie Wiadomości Krakowskie” (dalej: „OWK”) 11.06.1936, nr 164, s. 5.

${ }_{18}$ APP, ANA, Prośba o łaskę Do Pana Prezydenta Rzeczypospolitej Polskiej, napisana przez byłego kpr. Józefa Leję przebywającego w więzieniu śledczym WSO nr VII w Poznaniu, Poznań 22.02.1935 r., sygn. 33, s. 3, nlb. 
kpr. Romuald Gadomski z 86 pp $^{19}$. Neusser z pewnością nie przypuszczał, że jego klientem jest przyszły komunistyczny wicedyrektor Ministerstwa Bezpieczeństwa Publicznego.

Ucieczkom żołnierzy z wojska towarzyszyły inne przestępstwa. Ich popełnienie również groziło poważnymi konsekwencjami karnymi. Nie zmienia to faktu, że kary, jakie zapadały w drugiej połowie lat 20 . i w latach 30 ., były raczej łagodne. Jak inaczej ocenić wyrok 8 lat więzienia, który 21 listopada 1934 roku zasądził WSO nr 3 w Białymstoku? Tego dnia, na wyjazdowej sesji w Suwałkach białostocki sąd wojskowy skazał na 8 lat więzienia ułan. Piotra Daniłowicza. Skazany nie tylko wcześniej zbiegł z 2 Pułku Ułanów (dalej: PU), ale także zastrzelił swojego ojca, który odmówił mu wydania pieniędzy. Daniłowicz, jak pisało krakowskie „Tempo Dnia”, miał „bogatą przeszłość kryminalną” - na swoim koncie miał już 20 wyroków sądowych ${ }^{20}$. Bardziej surowo potraktowano szer. Tadeusza Jaworskiego, który zbiegł z 45 pp z Równego, gdzie był żołnierzem wyjątkowo niesubordynowanym. Po ucieczce dopuścił się licznych rabunków. W połowie sierpnia 1933 roku w Dąbrowie Górniczej na zlecenie Stefana Chachlowskiego Jaworski zamordował jego żonę Marię, która trudniła się prostytucją. Przed zastrzeleniem kobiety Jaworski upił ją. 19 kwietnia 1935 roku WSO w Krakowie skazał Jaworskiego na dożywocie ${ }^{21}$.

Wielu dezerterów pałało żądzą zemsty za faktyczną czy też urojoną krzywdę, której niegdyś doświadczyli. Z żądzy odwetu, tuż po porzuceniu macierzystych garnizonów, popełniali okrutne zbrodnie. Nie można wykluczyć, że pewna liczba zbiegów, jak twierdził Adolf Malinowski, miała poważne problemy psychiczne. Wybitny przedwojenny psychiatra wojskowy ocenił, że „przewaga samowolnych oddaleń i dezercji przypada na psychopatów o niestałej równowadze psychicznej lub upośledzonych w rozwoju umysłowym”22. Czy jeśli rzeczywiście tak było, mogła to być okoliczność łagodząca?

W historii przedwojennego sądownictwa wojskowego, funkcjonującego w warunkach pokojowych (tj. po traktacie ryskim w marcu 1921 roku) wobec dezerterów orzekano również karę śmierci, jednak WSO wymierzały tę karę sporadycznie. Na śmierć skazywały najczęściej powoływane w nadzwyczajnych

${ }^{19}$ APP, ANA, Sprawa karna kpr. Gadomskiego, odwołanie skierowane do Najwyższego Sądu Wojskowego w Warszawie przez WSO nr VII w Poznaniu, pismo podpisane przez [płk.] dr. [Antoniego] Neussera, Poznań 20.12.1932 r. sygn. 30, s. 1-3, nlb.

20 Utan-dezerter zamordowat ojca, „Tempo Dnia” 21.11.1934, nr 326 (586), s. 5.

${ }^{21}$ Kronika Krakowa. Morderca-dezerter przed sądem wojskowym, „OWK” 21.04.1935, nr 111, s. 6.

${ }^{22}$ A. Malinowski, Ekspertyzy sadowo-psychiatryczne w wojsku, Warszawa 1937, s. 14. 
okolicznościach tzw. Wojskowe Sądy Doraźne (dalej: WSD)23. Już w 1920 roku, czyli w warunkach wojny polsko-bolszewickiej WSD orzekły 333 wyroki śmierci, z których 125 skazanych było dezerterami. Rok później na mocy wyroków tych sądów wykonano jedynie 22 wyroki śmierci ${ }^{24}$. O potrzebie powoływania postępowania doraźnego decydował minister spraw wojskowych, który mógł w wyjątkowych okolicznościach przekazać takie upoważnienie dowódcom okręgu korpu$\mathrm{su}^{25}$. WSD rozpatrywały sprawy dezerterów w przyspieszonym trybie. Dotyczyły one szczególnie okrutnych przestępstw, których sprawcami byli zbiegli żołnierze, a które bulwersowały opinię publiczną. Przykładowo w latach 1934-1936 WSD orzekł wobec dezerterów dwa wyroki śmierci, które wykonano przez rozstrzelanie. W 1934 roku skazanym był strz. Stanisław Sroka, który służył w 5 Pułku Strzelców Podhalańskich (dalej: PSP). Żołnierz we wrześniu 1934 roku uciekł z karabinem ze swojego pułku. W okolicach Łańcuta w akcie zemsty zastrzelił dwóch mężczyzn, którzy kilka lat wcześniej go pobili. Przez krótki czas ukrywał się w lasach, potem dobrowolnie zgłosił na policję w Nisku. W połowie listopada 1934 roku rozpoczął się jego proces, przebiegał bardzo szybko. Sąd już na wstępie odrzucił wniosek obrońcy o psychiatryczne przebadanie oskarżonego ${ }^{26}$. Sroce nie pomogło też odwołanie się do łaski prezydenta - odpowiedź była odmowna. Wyrok sądu w Przemyślu osobiście zatwierdził gen. dyw. Janusz Głuchowski, dowódca Okręgu Korpusu (dalej: OK) nr X w Przemyślu. 16 listopada 1934 roku egzekucję wykonał pluton 5 PSP $^{27}$.

Krótki był proces strz. Stefana Grendy, dezertera z 20 pp. Grenda w noc sylwestrową 1935 roku zabrał z krakowskiego pułku karabin i po dotarciu do Zakopanego przez kilkanaście dni ukrywał się w tatrzańskim szałasie. 12 stycznia 1935 roku zamordował i obrabował inż. Stefana Dyljona. Ten znany i ceniony w firmie „Solvay” urzędnik samotnie wędrował na nartach górskim szlakiem i zupełnie przypadkowo spotkał swojego przyszłego mordercę. Jeszcze tego samego dnia Grenda przebrany w odzież swojej ofiary zamieszkał w hotelu „Morskie Oko” i wybrał się na jeden $\mathrm{z}$ filmów w zakopiańskim kinie ${ }^{28}$. Zatrzymano go kilka-

${ }^{23}$ Wprowadzenie sądów doraźnych na terenie całej Polski nastąpiło 24.07.1920 r. Podstawę działania trybu doraźnego w sądownictwie wojskowym w warunkach pokojowych II RP stanowił natomiast rozkaz ministra spraw wojskowych z 01.04.1922 r. Zob. T. Szczygieł, Wojskowe postepowanie karne w II Rzeczypospolitej (1918-1939), Katowice 2017, s. 324-325.

${ }^{24}$ W. Kozielewicz, Tryb doraźny - uwagi de lege ferenda, „Krytyka Prawa”, 2010, t. 10, nr 1, s. 333.

${ }^{25}$ R. Ostafiński-Bodler, Sady wojskowe w Polskich Siłach Zbrojnych i ich kompetencje w sprawach karnych w latach 1914-2002, Toruń 2002, s. 128.

${ }^{26}$ Przemyśl (PAT), Dezerter podwójnym morderca, OWK 16.11.1934, nr 326, s. 1.

27 Wiadomości z kraju. Wyrok śmierci w Przemyślu, „Nowy Dziennik” 17.11.1934, nr 315, s. 9.

${ }^{28}$ (s), Tragedia samotnego narciarza w Tatrach. Ofiara zbrodniczego dezertera z Chorzowa, „Siedem Groszy” 27.01.1936, nr 26, s. 1. 
naście dni później w Chorzowie. Proces trwający od 3 do 7 lutego 1936 roku przed WSD z uwagą śledziła prasa w całym kraju. Grenda był opisywany jako pozbawiony wyrzutów sumienia i zdemoralizowany dewiant, który po dokonanym morderstwie zjadł w hotelu obfitą kolację. Pogrubioną czcionką podkreślano fakt, że dezerter morderca urodził się w Westfalii. Wskazywano również, że Grenda nienormalnie zachowywał się w czasie służby wojskowej. Sosnowiecki „Kurier Zachodni” przypominał, że „był karany za to, że stojąc na baczność jadł marchew i śmiał się”29. Łódzka „Ilustrowana Republika” szła jeszcze dalej, sugerując, że dezertera, który lubił pudrować i malować sobie twarz, łączyła homoseksualna miłość z nastoletnim chłopcem. Jak pisano: „na salę wchodzi świadek Nowak, 15-letni chłopiec z Chorzowa. Jest to postać w procesie bardzo ciekawa, gdyż Nowaka łączy z Grendą jakiś stosunek, o którym obydwaj milczą"30. Piętnastolatek zeznał, że Grenda kilkakrotnie zapraszał go do kina i chciał dawać mu prezenty.

Taki wizerunek medialny z pewnością nie pomagał oskarżonemu. Zebrany WSD w Krakowie, którego posiedzeniu przysłuchiwał się również dowódca 6 Dywizji Piechoty gen. bryg. Bernard Mond nie znalazł żadnych okoliczności łagodzących. Nie przeprowadzono także badań psychiatrycznych, o co zabiegał obrońca Grendy, kpt. dr Krupa. Dezerter i morderca inżyniera został rozstrzelany 7 lutego $1936 \mathrm{roku}^{31}$. Niewykluczone, że na los strz. Sroki i strz. Grendy wpłynął także brak autorytetu i kwalifikacji obrońcy - adwokaci Sroki i Grendy być może nie mieli takiego doświadczenia, jak opisany wcześniej płk Neusser czy krakowski mecenas dr Leopold Süsser.

Dr Süsser, właściciel kancelarii adwokackiej przy krakowskim Placu Dominikańskim $5^{32}$, był równie skuteczny jak Neusser. Jesienią 1935 roku wybronił zbiegłego do Niemiec z 11 pułku piechoty szer. Ryszarda Morysia. Dezerter przebywał w Niemczech od końca maja do połowy sierpnia tego roku. Sprawa wydawała się przesądzona, ponieważ wojskowi psychiatrzy zgodnie orzekli, że szer. Moryś jest zupełnie zdrowy psychicznie i powinien ponieść pełną odpowiedzialność karną. Mimo to Süsser nie zrezygnował i w linii obrony posiłkował się opiniami policji, która w rodzinnej miejscowości Morysia Wielkie Hajduki [dziś część Chorzowa - R.K.] przeprowadziła wywiad środowiskowy. Policjanci mieli ustalić, że dezerter uchodził tam za umysłowo niedorozwiniętego. Süsser dowo-

${ }^{29}$ Dezerter $i$ morderca z Tatr przed doraźnym sądem wojskowym, „Kurier Zachodni” 06.02.1936, nr 36, s. 2.

${ }^{30}$ Morderca inż. Dyljona przed sadem. Grenda zdezerterowat z pułku. - Jak zostat zastrzelony ś.p Dyljon. - Zbrodniarz malowat sobie brwi, wargi i policzki. - Wyrok ogłoszony będzie jutro, „Ilustrowana Republika” 06.02.1936, nr 36, s. 7.

${ }^{31}$ Morderca inż. Dyljona zostat wczoraj rozstrzelany, „Kurier Zachodni” 08.02.1936, nr 38, s. 2.

${ }^{32}$ Zob. Kalendarz Sadowy na rok 1930, oprac. J. Kirkiczenko, M. Kraczkiewicz, Warszawa 1930, s. 147. 
dził, że wobec upośledzonego psychicznie żołnierza, który dobrowolnie powrócił z krótkiej dezercji z Niemiec do Polski, należy zastosować najniższy wymiar kary. Ostatecznie sąd podzielił tę opinię i uwzględniając czas spędzony $\mathrm{w}$ areszcie przez byłego strzelca 11 pp, orzekł, że dezerter wyjdzie na wolność za dwa miesiące. Nic dziwnego, że śledzące z uwagą ten proces krakowskie „OWK” określiły go jako sensacyjny ${ }^{33}$. Süsser w kolejnych latach skutecznie przekonywał sędziów do zmiany kwalifikacji czynu. Tak było między innymi 11 lipca 1936 roku, kiedy dwóch dezerterów ze wspomnianego 11 pp początkowo oskarżano nie tylko o dezercję do Niemiec, ale także o przekazanie Abwehrze tajnych informacji. Krakowski adwokat okazał się skuteczny - ucieczka żołnierzy została uznana za samowolne oddalenie się od oddziału, a udzielnie informacji Niemcom ocenione jako nieumyślne ${ }^{34}$. Skutkowało to znacznym zmniejszeniem odpowiedzialności karnej.

Kluczowe w obronie żołnierzy, którzy zbiegli za granicę, było, aby sąd nie uznał ich za szpiegów uznając, że informacje udzielone przez nich Rosjanom, Niemcom, Litwinom i Czechom nie miały poważnych konsekwencji dla bezpieczeństwa i obronności strony polskiej. Skazując 9 czerwca 1932 roku strz. Józefa Otrembnika, żołnierza 16 pp na 2 lata i 3 miesiące ciężkiego więzienia, sąd uniewinnił dezertera $\mathrm{z}$ tarnowskiego pułku piechoty z zarzutu świadomego udzielenia informacji niemieckiemu wywiadowi na temat $16 \mathrm{pp}$. Nie dał jednak wiary, że oskarżony nie wiedział, co to jest „tajemnica wojskowa”. Sąd nie uwzględnił zażalenia krakowskiego adwokata dr. Marcelego Birnbauma, który dowodził, że dezerter wychował się bez rodziców i świadomości narodowościowej i jest opóźnionym umysłowo analfabetą. Dr Birnbaum przekonywał, że „oskarżony jest prawie analfabetą, sierotą wychowanym pod zaborem pruskim - jego cała rodzina przebywa na Śląsku niemieckim, tak że trudno od niego wymagać odpowiedniego poczucia obowiązków obywatelskich" ${ }^{35}$. Birnbaum, specjalizujący się w sprawach karnych i wojskowych, nie wygrał. Jego apelację we wrześniu 1932 roku odrzucił NSW w Warszawie. Pod decyzją podpisał się gen. bryg. Emil Mecnarowski. Strategia stosowana przez Birnbauma i Süssera - pokazywanie ciężkiego dzieciństwa, upośledzenia umysłowego żołnierzy, analfabetyzmu i nierozumienia patriotyzmu - była skuteczna, sprawdzała się zwłaszcza w wypadku służących w WP żołnierzy ukraińskich i białoruskich.

${ }^{33}$ Sensacyjny proces o dezercje w Krakowie, „OWK” 29.11.1935, nr 331, s. 3.

${ }^{34}$ Tajna rozprawa przed sadem wojsk. w Krakowie, „OWK”13.07.1936, nr 196, s. 9.

${ }^{35}$ WBH, Akta Spraw Sądów i Prokurator Wojskowych (dalej: ASSPW), Wywód zażalenia podpisany przez adwokata dr. Marcelego Birnbauma dot. wyroku z dnia 9.06.1932 r. dot. strz. Józefa Otrembnika przebywającego w więzieniu śledczym w Krakowie, przesłany przez WSO nr V w Krakowie do NSW w Warszawie, Kraków 18.06.1932 r., sygn. I.351.33.183., s. 3, nlb. 
Wobec ucieczek Białorusinów i Ukraińców stosowano pewną taryfę ulgową. Warunkiem złagodzenia wyroków było dowiedzenie, że dezerterów nie inspirowali komuniści lub nacjonaliści. Słaba znajomość języka polskiego, zapóźnienie kulturalne, a także wspomniany analfabetyzm okazywały się niezwykle przydatne. Takie okoliczności łagodzące sąd zastosował wobec białoruskich szeregowców, którzy latem 1927 roku zbiegli z 33 pp w Łomży. Włodzimierz Żyżyc, Szymon Kościukiewicz i Michał Czernik 17 lipca 1927 roku porzucili swój pułk, udając się w kierunku Niemiec, szybko jednak zostali złapani. Ze skruchą przyznali się do winy przed WSO w Warszawie, tłumacząc się między innymi słabą znajomością języka polskiego. W swojej jednostce mieli być żołnierzami „drugiej kategorii”. Decyzję o dezercji Białorusini motywowali strachem przed zbliżającymi się manewrami 33 pp. Wiele wskazywało, że wobec dezerterów złagodzono wyroki: „Sąd biorąc pod uwagę okoliczności łagodzące, jak niski poziom umysłowy oskarżonych oraz przyznanie się do winy, zasądził ich do 9 miesięcy więzienia"36. Relację „Polski Zbrojnej” potwierdzały wyroki wydawane w kolejnych latach.

Pobłażliwość sądownictwa wojskowego względem białoruskich i ukraińskich dezerterów dobrze ukazało śledztwo toczące się w listopadzie i grudniu 1931 roku przeciwko Stefanowi Malinowskiemu. Białoruski żołnierz służący w $26 \mathrm{Pułku}$ Ułanów zbiegł w lipcu 1923 roku z aresztu śledczego w Słonimie do ZSRR, skąd powrócił dopiero w kwietniu 1931 roku. Został zatrzymany przez patrol KOP. Białorusin podczas rozprawy nie okazał skruchy, a swój powrót tłumaczył tęsknotą za rodziną. Szczerze również przyznał, że liczył, iż po upływie tak długiego czasu jego sprawa uległa przedawnieniu. WSO nr IX w Brześciu uzasadniał niski, dwuletni wyrok więzienia kilkoma faktami. Okolicznościami łagodzącymi były przyznanie się do winy, brak uświadomienia obywatelskiego i wyszkolenia wojskowego. Jednak kluczowe znaczenie miało orzeczenie sądu, że Malinowski nie jest szpiegiem sowieckim: ,wreszcie osoba półanalfabety, nie władającego zupełnie językiem polskim, przedstawiała się, zdaniem Sądu, jako materiał dla celów szpiegowskich wartości więcej niż wątpliwych"37. Od wyroku do NSW w Warszawie odwołała się prokuratura w Brześciu. Jednak warszawski NSW w maju 1932 roku utrzymał w mocy wyrok sądu z 2 grudnia 1931 roku.

Po długim śledztwie w marcu 1929 roku WSO nr VI we Lwowie całkowicie uniewinnił także ukraińskiego szer. Wasyla Ratusznego. Ukrainiec służył w łowickim 10 pp, skąd zdezerterował i od połowy lutego do połowy marca 1928 roku ukrywał się w ZSRR. Po powrocie do Polski został zatrzymany. Bardzo ciekawe

\footnotetext{
${ }^{36}$ Dezerterzy, „Polska Zbrojna” 22.11.1927, nr 320, s. 4.

37 WBH, ASSPW, Wyrok w Imieniu Rzeczypospolitej Polskiej WSO nr IX w Brześciu n. Bugiem nr KO 114/31 wobec ułan. Stefana Malinowskiego, żołnierza 26 PU w Baranowiczach, Baranowicze 2.12.1929 r., sygn. I.351.33.7., s. 9, nlb.
} 
było, że lwowski sąd w orzeczeniu nie wziął pod uwagę, że dezerter przebywał w kijowskiej siedzibie Głównego Zarządu Wywiadowczego (Gławnoje Razwiedywatielnoje Uprawlenije) (dalej: GRU) ${ }^{38}$. Ratusznego bronił lwowski adwokat Stanisław Mrozowski, ale nie wydaje się, by miało to znaczenie w tym wypadku.

Uwolnienie Ratusznego zszokowało lwowską prokuraturę. Oburzenia nie krył płk dr Marian Stampf'l, który pełnił obowiązki lwowskiego prokuratora w WSO nr VI. Kilka dni po ogłoszeniu tego wyroku w złożonym do NSW w Warszawie zażaleniu płk Stampf'l pisał, że stanowisko sądu ,jest mylne pod względem faktycznym i nie wytrzymuje żadnej logicznej krytyki". 2 lutego 1929 roku dowodził, że dla zbiegostwa szer. Ratusznego nie ma żadnego usprawiedliwienia. W apelacji do NSW wręcz wyśmiewał naiwną sentencję lwowskiego sądu, który stwierdził, że podczas pobytu w ZSRR żołnierz nie nawiązał żadnych kontaktów z GRU. Płk Stampf'l przypomniał, że na taki wyrok nie liczył nawet adwokat dezertera ${ }^{39}$. Całkiem możliwe, że szer. Ratuszny po powrocie ze Związku Sowieckiego został zwerbowany przez O. II WP i w zamian za abolicję przekazywał Sowietom fałszywe informacje, nie potwierdza tego jednak zachowana dokumentacja.

Wśród wielu podobnych procesów toczących się przed WSO we Lwowie zaskakiwał także niski wyrok zasądzony dla chor. Mateusza Moskwy. Ten zawodowy żołnierz z 54 pp w Tarnopolu otrzymał 8 czerwca 1927 roku karę roku więzienia. W połowie lipca 1926 roku chor. Moskwa uciekł do ZSRR i przez pewien czas mieszkał w Kijowie. 7 września nielegalnie wrócił do Polski. W śledztwie pojawiły się poszlaki wskazujące, że nawiązał kontakty z mieszczącym się w tym mieście oddziałem Zjednoczonego Państwowego Zarządu Politycznego (Objedinionnoje Gosudarstwiennoje Politiczeskoje Uprawlenije), czyli OGPU. Dochodzenie wykazało także, że podoficer jeszcze przed ucieczką pożyczył od kilkunastu żołnierzy pułku około 140 zł. Przesłuchiwani świadkowie zgodnie potwierdzali, że Moskwa nie krył sympatii politycznych wobec ZSRR. Po powrocie do Polski miał przy sobie fałszywe dokumenty na nazwisko Stanisław Berezowski, a także pistolet $\mathrm{z}$ amunicją (ten sam, z którym zbiegł). Miał też 200 dolarów i 36 zł. Sąd uwolnił Moskwę od zarzutu zbrodni szpiegostwa, sądząc go jedynie za dezercję. Poza wymierzeniem kary roku pozbawienia wolności, na poczet którego zaliczono czas spędzony w areszcie (od 18 września 1926 do 8 czerwca 1927 roku), podoficer 54 pp został zdegradowany do stopnia

${ }^{38}$ WBH, ASSPW, Odpis wyroku w Imieniu Rzeczypospolitej Polskiej WSO nr VI we Lwowie nr KO 740/28 wobec szer. Wasyla Ratusznego, żołnierza 10 pp w Łowiczu, Lwów 27.03.1929 r., sygn. I.351.33.183, s. 1-11, nlb.

${ }^{39}$ WBH, ASSPW, Zażalenie nieważności dot. wyroku nr KO 740/28 złożone przez prokuraturę przy WSO nr VI we Lwowie do NSW w Warszawie, podpisane przez płk. Dr. [Mariana] Stampf'la, prokuratora wojskowego, Lwów 02.04.1929, sygn. I.351.33.183, s. 1-7, nlb. 
szeregowca ${ }^{40}$. Od wyroku odwołała się kilka dni później lwowska prokuratura. 15 października 1927 roku NSW w Warszawie pod przewodnictwem gen. bryg. Stanisława Śliwińskiego odrzucił zażalenie lwowskiej prokuratury.

Obronę chor. Moskwy prowadzili dwaj adwokaci: we Lwowie dr Roman Aleksandrowicz, w Warszawie, przed NSW - mecenas Stanisław Rundo. Nie wiadomo, co zdecydowało o zaskakująco łagodnym wymiarze kary. Można przypuścić, że dezercja chor. Moskwy była pozorna, a w rzeczywistości stanowiła realizację misternego planu kontrwywiadowczego. Dla uwiarygodnienia dezercji żołnierz tarnopolskiego pułku świadomie niszczył swoją reputację, przed ucieczką pożyczając pieniądze od innych żołnierzy i wychwalając w pułku stosunki polityczno-społeczne w Związku Sowieckim. Warto zwrócić uwagę, że chor. Moskwa w czasie procesu zeznał, że sowiecki wywiad posiada dokładne rozpoznanie 12 Dywizji Piechoty. Łagodna kara dla chor. Moskwy, który dopuścił się licznych przewinień, z pewnością zdumiewała. Moskwa posługiwał się fałszywymi dokumentami, dysponował gotówką niewiadomego pochodzenia, wcześniej przywłaszczył sobię pieniądze żołnierzy z macierzystego pułku. Od chorążego wymagano znacznie więcej niż od szeregowca. Chorąży miał pielęgnować etos pułku, kształtować postawy obywatelskie, a nie zachwalać ZSRR, co mogło być traktowane jako podżeganie innych żołnierzy do ucieczki.

Ciekawe, że dla setek szeregowców w porównywalnych sprawach karnych wojskowe sądy nie znajdowały okoliczności łagodzących. WSO nr I w Warszawie 29 listopada 1927 roku skazał szer. Stanisława Szmigielskiego z 3 komp. 15 pp na rok pozbawienia wolności. Szer. Szmigielski poza namawianiem do dezercji jednego z żołnierzy i zachwalaniem idei komunistycznych, w maju 1927 roku samowolnie oddalił się z pułku na kilka dni ${ }^{41}$. W lutym 1936 roku WSO w Warszawie skazał strz. Romana Filuka z 72 pp na 6 lat więzienia. Ukraińskiemu żołnierzowi zarzucono agitację komunistyczną, a także zachęcanie do ucieczki dwóch swoich rodaków, którzy wraz z nim służyli w radomskim pułku. Przy Filuku znaleziono również wojskowe notatki. Filuk i jego koledzy zdezerterowali z $72 \mathrm{pp}^{42}$. Warszawski sąd nie dał wiary, że zapiski w jego zeszycie to tylko notatki z wykładów w szkole podoficerskiej.

Dość surowo traktowano świadome przekazywanie informacji wojskowych organizacjom terrorystycznym i wywiadom państw sąsiednich. 29 września 1933

${ }^{40}$ WBH, ASSPW, Wyrok w imieniu Rzeczypospolitej Polskiej wobec chor. Mateusza Moskwy, zaw. żołn. 54 pp w Tarnopolu, nr KO 906/28 WSO nr VI we Lwowie, Lwów 08.06.1927, sygn. I.351.33.7., sygn. I.351.33.7, s. 1-11, nlb.

${ }^{41}$ WBH, ASSPW, Wyrok w imieniu Rzeczypospolitej Polskiej wobec szer. Stanisława Szmigielskiego, nr KO 681/27 WSO nr I w Warszawie, Warszawa 29.11.1927, sygn. I.351.33.7., s. 1-7, nlb.

${ }^{42}$ WBH, ASSPW, Wyrok w imieniu Rzeczypospolitej Polskiej wobec strz. Romana Filuka, nr KO 972/35 WSO nr I w Warszawie, Warszawa 24.02.1936 r., sygn. I.351.33.7., s. 1-15, nlb. 
roku WSO we Lwowie skazał st. strz. Wasyla Pokotyło z 69 pp na 8 lat ciężkiego więzienia. Śledztwo wykazało, że ukraiński żołnierz służący w gnieźnieńskim pułku podczas urlopu przekazał członkom Organizacji Ukraińskich Nacjonalistów własnoręcznie sporządzony szkic koszar $69 \mathrm{pp}^{43}$. Taki sam wyrok orzekł WSO nr III w Wilnie wobec kpr. Wacława Pietraszki, który miał zbierać informacje dla strony litewskiej. Wyrok 8 lat więzienia dla kpr. Pietraszki, który był Litwinem, został utrzymany w mocy, mimo oceny, że przekazywane dokumenty nie miały większej wagi dla litewskiego wywiadu ${ }^{44}$. Trzeba zaznaczyć, że żołnierze skazani w Wilnie i we Lwowie nigdy nie dopuścili się dezercji.

Na 10 lat ciężkiego więzienia skazywano zazwyczaj dezerterów, którzy nawiązywali trwałą współpracę z wywiadami wojskowymi państw graniczących z Polską. Taką karę otrzymał strz. Tadeusz Rudolf z 3 PSP. Za dezercję w 1929 roku skazywano go dwukrotnie. Nie tylko przekazywał informacje niemieckiemu wywiadowi na terenie Wolnego Miasta Gdańska, ale też, w połowie października 1929 roku, ukradł z żywieckiej Powiatowej Komendy Uzupełnień ponad 1500 akt (sic!). Nic dziwnego, że NSW w Warszawie odrzucił apelację w sprawie jego wyroku i utrzymał dla Rudolfa karę 10 lat więzienia ${ }^{45}$. W lutym 1936 roku WSO nr VIII w Grudziądzu także nie miał wątpliwości, ogłaszając karę 10 lat więzienia dla uł. Pawła Cichosa. Były żołnierz 18 PU nie tylko opuścił swój pułk na początku października 1933 roku i przedostał się do Niemiec, skąd powrócił dwa lata później. W niemieckim Schlochau [obecnie Człuchów - R.K.] rozpoczął intensywną agitację na rzecz swojej nowej ojczyzny. Jesienią 1933 roku bezskutecznie nakłaniał jednego z polskich dezerterów do szpiegowania na rzecz Niemiec. Cichos wysłał również list do komendanta chojnickiego Przysposobienia Wojskowego, w którym nakłaniał go przekazywania Niemcom wszelkich informacji o polskich siłach zbrojnych. W liście z grudnia 1933 roku zaadresowanym do jednego z żołnierzy toruńskiego 4 Pułku Lotniczego (dalej: PL) prosił o udzielenie mu wyczerpujących informacji o eksploatowanych samolotach. Szczególnie interesowały go schematy techniczne kompresorów i wbudowanych CKM-ów w maszynach wyprodukowanych w PZL. Podczas procesu toczącego się w styczniu i lutym 1936 roku Cichos argumentował, że nie były to agitacje szpiegow-

${ }^{43}$ WBH, ASSPW, Odpis wyroku w Imieniu Rzeczypospolitej Polskiej WSO nr VI we Lwowie nr KO 332/33 wobec strz. Wasyla Pokotyło, żołnierza 69 pp w Gnieźnie, Lwów 29.09.1933, sygn. I.351.33.183., s. 1-12, nlb.

${ }^{44}$ WBH, ASSPW, Odpis wyroku w Imieniu Rzeczypospolitej Polskiej WSO nr III w Wilnie nr Ko274/31 wobec kpr. Wacława Pietraszko, żołnierza sł. czyn. 5 pp leg. w Wilnie, Wilno 18.01.1933, sygn. I.351.33.183., s. 2-3, 5., nlb.

${ }^{45}$ WBH, ASSPW, Uchwała NSW w Warszawie dot. strz. Tadeusza Rudolfa, żołnierza 3 PSP, podpisana przez gen. bryg. Emila Mecnarowskiego przewodniczącego NSW, Warszawa 27.10.1930 r., sygn. I.351.33.183, nlb. 
skie, a jedynie próba okazania stronie niemieckiej, że nie został przysłany do III Rzeszy przez polski wywiad ${ }^{46}$. Taka argumentacja nie przekonała sądu. Również dwukrotnie - w sierpniu 1936 i czerwcu 1937 roku - NSW w Warszawie oddalił prośbę Cichosa o wznowienie postępowania karnego w jego sprawie.

Wyrok 10 lat więzienia za ucieczkę za granicę i ujawnienie tajemnic wojskowych nie był regułą. 5 kwietnia 1929 roku szer. Jan Skrzypiec z krakowskiego 2 PL został skazany jedynie na 4 lata więzienia o zwykłym rygorze, a przestępstwa, jakie miał na sumieniu, były wcale niemałe. $W$ trakcie prawie dwuletniej dezercji - od kwietnia 1926 do marca 1928 roku - Skrzypiec ujawnił wrocławskiej placówce Abwehry informacje związane z lotnictwem wojskowym w Polsce. Twierdził, że uciekł, ponieważ chciał służyć w marynarce wojennej, a nie w lotnictwie. Tymczasem podczas śledztwa ustalono, że żołnierz pochodził ze śląskiej rodziny o tradycjach patriotycznych, a do wojska zgłosił się na ochotnika. Niestety w krakowskim pułku lotniczym nie miał dobrej opinii; „pełni tam służbę do dnia 9 kwietnia 1926 r. W czasie tym karany jest kilkakrotnie dyscyplinarnie za niesubordynację, spanie na posterunku i samowolne oddalenie się z 24-tej eskadry lotniczej w Krakowie w związku z podejrzeniem go o usiłowanie zgwałcenia, popełnione w czasie pełnienia służby wartowniczej. Cieszył się [!] opinią żołnierza złego, bez poczucia obywatelskiego, niezdyscyplinowanego, wywierającego na otoczenie wpływ demoralizujący" ${ }^{47}$. Skrzypiec do zarzutów szpiegostwa się nie przyznał. WSO informację na temat jego kontaktów z Abwehrą uzyskał od współwięźniów przebywających $\mathrm{w}$ celi śledczej z oskarżonym.

W trakcie procesów sądy zazwyczaj krytycznie odnosiły się do relacji o torturach, jakim miano poddawać dezerterów z WP w Niemczech, Czechosłowacji, Związku Sowieckim i na Litwie. Powracający lub deportowani z tych krajów dezerterzy, a także ich obrońcy próbowali dowodzić, że informacje przekazywane GRU lub Abwehrze były wymuszone siłą. Taką argumentację sądy prawie zawsze odrzucały, jak w opisanym wcześniej procesie szer. Ratusznego. Sąd jednoznacznie stwierdził, że z pozyskanych informacji wynika, że sowieckie służby traktują dezerterów bardzo łagodnie ${ }^{48}$. Nie inaczej było przy ogłoszeniu 6 lat więzienia dla szer. Michała Misiukiewicza z 4 komp. 85 pp. Sąd skazując dezertera nie uwie-

${ }^{46}$ WBH, ASSPW, Odpis Aktu Oskarżenia przed WSO nr VII w Grudziądzu wobec uł. Pawła Cichosa, dezertera z 18 PU, Grudziądz 22.01.1936 r., sygn. I.351.33.213, s. 2-3, 7, nlb.

${ }^{47}$ WBH, ASSPW, Wyrok w imieniu Rzeczypospolitej Polskiej Ko:284/28 WSO nr V w Krakowie przeciwko szer. Janowi Skrzypcowi z 2 PL, podpisany przez mjr. [Kaliksta] Szymonowicza, sędziego orzekającego, Kraków 05.04.1929, I.351.33.183., s. 5, nlb.

${ }^{48}$ WBH, ASSPW, Odpis wyroku w Imieniu Rzeczypospolitej Polskiej WSO nr VI we Lwowie nr KO 740/28 wobec szer. Wasyla Ratusznego, żołnierza 10 pp w Łowiczu, Lwów 27.03.1929 r., sygn. I.351.33.183, s. 6, nlb. 
rzył jego zeznaniu, że przekazał tajemnicę wojskową stronie litewskiej, ponieważ grożono mu bronią: „z orzeczenia biegłego wynika, że wywiad litewski odnośnie dezerterów z Polski nie stosuje terroru, gdyż znaną jest rzeczą ogólnie, że dezerterzy wszystkie wiadomości, jakie posiadają o wojsku polskim, chętnie ujawniają obcemu wywiadowi”49.

Polskie sądy zdawały sobie sprawę, że duża liczba dezercji za granicę wynikała z faktu, że była to jedyna możliwość uniknięcia surowego wyroku w kraju. Dotyczyło to zwłaszcza morderców i sprawców rozbojów ze skutkiem śmiertelnym. Za granicę uciekali też żołnierze, którzy z premedytacją lub w afekcie mordowali w czasie służby swoich kolegów. Jedno z takich tragicznych wydarzeń rozegrało się na początku lipca 1928 roku przy granicy polsko-sowieckiej. 5 lipca 1928 roku żołnierz KOP szer. Paweł Kicuła zabił swojego kolegę szer. Eugeniusza Dorocha i zbiegł do Rosji. Strona polska była w tej sytuacji bezradna. 17 sierpnia 1928 roku zebrała się polsko-sowiecka komisja graniczna i podpisała dwujęzyczny protokół, z którego jednoznacznie wynikało, że poszukiwany zbrodniarz dezerter Kicuła odmówił powrotu do Polski - nic więcej nie dało się zrobićs ${ }^{50}$. W listopadzie 1928 roku strona sowiecka wykazała się dobrą wolą - przekazano Polsce dwa karabiny i bagnet, które po morderstwie szer. Kicuła zabrał do ZSRR.

Szer. Kicuła, który próbował już w 1925 roku zbiec do Rosji Sowieckiej, był nieprzerwanie poszukiwany w kolejnych latach. Pod koniec czerwca 1938 roku pluton żandarmerii w Stanisławowie meldował do wojskowego prokuratora w Lublinie, że szer. Kicuła przebywa w ZSRR. Raportowano ponadto, że żandarmeria intensywnie pracuje nad ustaleniem jego adresu ${ }^{51}$. Z zachowanych źródeł nie wynika, czy się to udało.

Polskie sądy wojskowe brały pod uwagę możliwość karania polskich dezerterów za różne przestępstwa przez zagraniczne sądy, a w konsekwencji deportowanie ich do kraju. Jak w przypadku odrzucenia przez NSW w Warszawie rewizji oskarżonego strz. Franciszka Kalcherta, którego w maju 1938 roku WSO nr III w Wilnie skazał na 3 lata i 6 miesięcy pozbawienia wolności. W uzasadnieniu wyroku napisano że „oskarżony jako uciążliwy przybysz kilkakrotnie

${ }^{49}$ WBH, ASSPW, Wyrok w imieniu Rzeczypospolitej Polskiej Ko:188/38 WSO nr III w Wilnie orzekający wobec strz. Michała Misiukiewicza przynależnego do 4 komp. 85 pp strz. wileńskich od 13.04.1934 r., sygn. I.351.33.212, s. 10, nlb.

${ }^{50}$ WBH, ASSPW, Odpis protokołu nadgranicznego spisanego 17.08.1928 r. m. starostą Kazimierzem Moszyńskim, pełnomocnikiem rządu RP i Piotrem Dołżenkowem, pełnomocnikiem rządu ZSRR, Ko 234/28, sygn. I.351.33.174., s. 73, nlb.

${ }^{51}$ WBH, ASSPW, Meldunek st. wach. żandarm. Ignacego Maleńczaka zastępcy plutonu żandarmerii Stanisławów skierowany do Wojskowego Prokuratura Okręgowego w Lublinie dot. wyników poszukiwań szer. Pawła Kicuły, Stanisławów 27.06.1938 r., sygn. I.351.33.174, nlb. 
karany w Niemczech został wydalony" "52. Przedwojenne sądy wojskowe w trakcie rozpraw brały także pod uwagę, czy zbiegli żołnierze „hańbili mundur”, tj. swoją postawą dyskredytowali dobre imię Rzeczypospolitej. Sąd ogłaszając wyrok roku i 3 miesięcy więzienia dla dezertera strz. Gerharda Skarbani z 6 komp. 11 pp WSO nr V w Krakowie, który w kwietniu 1935 roku zbiegł do Niemiec w upojeniu alkoholowym, co wydawało się okolicznością usprawiedliwiającą, uznał, że dezerter porzucając służbę w „takim stanie” naraził prestiż WP w oczach cudzoziemców ${ }^{53}$.

WSO karały nie tylko zatrzymanych przez OŻ i policję dezerterów, ale także żołnierzy, którzy im pomagali. Była to pomoc w wielu przypadkach niezgodna z prawem, wynikająca z więzów koleżeńskich łączących zawodowych żołnierzy od lat 1919-1920. Ciekawy przypadek miał miejsce w 1923 roku w Grodnie. Kpt. Adolf Półtoracki z tamtejszego 76 pp ukrywał w swoim mieszkaniu od 20 czerwca do 9 lipca 1923 roku sierż. zaw. Kazimierza Waśkiewicza z kaliskiego 29 pp. Sierż. Waśkiewicz był przydzielony do ekspozytury nr III O. II SG w Wilnie, skąd zdezerterował. Kpt. Półtoracki w czasie wojny polsko-bolszewickiej przyjaźnił się z bratem Kazimierza ppor. Marianem Waśkiewiczem. Ppor. Waśkiewicz służąc w 29 pp został ciężko ranny w bitwie w 1920 roku i umierając miał prosić kpt. Półtorackiego o opiekę nad swoim młodszym bratem Kazimierzem. Przestrzegał również brata, że kpt. Półtoracki ma słabość do alkoholu ${ }^{54}$. Kpt. Półtorackiemu wymierzono karę 8 miesięcy więzienia i wydalono go z wojska. Sąd uznał, że oficer świadomie ukrywał na przełomie czerwca i lipca 1923 roku zbiegłego w styczniu tego roku sierż. Waśkiewicza oraz, że w tę sprawę włączył także swojego ordynansa szer. Tomasza Niwińskiego. Oficer grodzieńskiego pułku został uwolniony z zarzutu szpiegostwa na rzecz Litwy, o co obwiniano sierż. Waśkiewicza, jednak Pótorackiemu postawiono inne zarzuty: nielegalnego przechowywania austriackiego karabinka typu Mannlicher i pobicia - w połowie stycznia 1924 roku na jednej z głównych ulic miasta, w obecności wielu świadków, pijany Półtoracki pobił policjanta. W niewielkim Grodnie był to skandal. Obrońca Półtorackiego adwokat Feliks Milewski próbował wykorzystać nietrzeźwość swojego

52 WBH, ASSPW, Wyrok w Imieniu Rzeczypospolitej Polski NSW w Warszawie K.N 230/38 z 15.07.1938 r. dot. rewizji wyroku WSO nr III w Wilnie z 19.05.1938 r. KO 80/38 złożonej przez oskarżonego strz. Franciszka Kalcherta, Warszawa 18.07.1938 r., s. 3, nlb.

53 WBH, ASSPW, Wyrok w imieniu Rzeczypospolitej Polskiej KO 27/36 WSO nr V w Krakowie przeciwko strz. Gerhardowi Skarbani, podpisany przez mjr. Alfreda Szymonowicza, przewodniczącego rozprawy, Kraków 20.02.1936 r., I.351.33.183., s. 8, nlb.

54 WBH, ASSPW, Odpis zażalenia nieważności od wyroku WSO nr III w Wilnie z dnia 14.03.1925 r. w sprawie kpt. Adolfa Półtorackiego, sierż. Kazimierza Waśkiewicza i szer. Tomasza Niwińskiego, sporządzony przez Feliksa Milewskiego adwokata kpt. Adolfa Półtorackiego, skierowanego przez WSO nr III w Wilnie do NSW w Warszawie, Wilno 22.03.1925, sygn. I.351.33.183., s. 2 , nlb. 
klienta na jego korzyść: „wezwani lekarze eksperci w swym jasnym, logicznym, opartym na całokształcie wywodzie, uzasadniając całkowitą niepoczytalność kapitana w dniu 18 stycznia 1924 roku, charakteryzowali całe podłoże psychiczne oskarżonego. Psychopatyczna i neurotyczna konstytucja, na którą złożyły się dziedziczne obciążenie alkoholem, spotęgowana samokokainizowaniem się pewien czas, następnie samoalkoholizowaniem się i kontuzją w głowę w czasie walk, była tłem, na którym nawet lekkie odurzenie się alkoholem spowodować mogło taki stan upicia się, iż oskarżony nie mógł rozumieć istoty i znaczenia dokonywanego czynu, ani kierować swoimi czynnościami" 55 . Wysiłki wileńskiego adwokata nie przyniosły oczekiwanych rezultatów. Po zacytowaniu przez Milewskiego opinii medycznej o byłym kapitanie 76 pp trudno było liczyć, aby nawet po ułaskawieniu mógł wrócić do czynnej służby wojskowej. Wyrok ośmiu miesięcy więzienia dla niego nie wydaje się surowy.

Co ciekawe, w wielu innych procesach argument „,nietrzeźwego stanu umysłowego dezertera" zyskiwał przychylność sądu. Działo się to szczególnie wsprawach dotyczących rezerwistów. Tak było w krakowskim procesie kpr. rez. Alfreda Oczkowskiego, kiedy w końcu października 1934 roku opisywany już wcześniej „specjalista od dezercji” adwokat Süsser dowiódł kolegium sędziowskiemu, że Oczkowski jedynie oddalił się z oddziału. Krakowski adwokat przekonał sąd, że oskarżony nie mógł również świadomie znieważyć WP, ponieważ był zamroczony alkoholem ${ }^{56}$.

Z analizy źródeł wynika, że w latach 1921-1939 polskie sądy (poza sporadycznymi przypadkami oraz wyłączywszy tryb postepowania sądów doraźnych) dość łagodnie traktowały zbiegostwo z armii. Dotyczyło to również recydywistów, którzy przed wojskiem weszli w konflikt z prawem. Ludzie z kryminalną przeszłością po wcieleniu do wojska zazwyczaj z niego uciekali. W czasie dezercji większość z nich dopuszczała się kolejnych przestępstw. Mimo to sądy dopuszczały możliwość, że nawet tak zdemoralizowani żołnierze mogą się poprawić. Dowodzi tego przypadek strz. Kazimierza Jędrzejczaka, winnego kilkukrotnej dezercji i wielu rabunków. Za kradzieże Jędrzejczak przebywał w więzieniu jeszcze przed rozpoczęciem służby wojskowej. W kwietniu 1934 roku, podczas dezercji w jednym z domów koło Pułtuska prawie udusił kobietę, domagając się od niej wydania oszczędności. W trakcie rozprawy sądu wojskowego Jędrzejczak podkreślał, że jest sierotą pozbawionym domu. Sąd po wysłuchaniu dramatycznego życiorysu dezertera wymierzył mu karę 4 lat więzienia. Jak zanotowały śledzą-

\footnotetext{
${ }^{55}$ Ibidem, s. 5.

${ }^{56}$ Kapral oskarżony o dezercje przed sądem, OWK 28.10.1934, nr 30, s. 6.
} 
ce przebieg procesu „Ostatnie Wiadomości Krakowskie”, sąd wziął pod uwagę okazaną przez dezertera skruchę 57 .

Rzeczywiście, wielu dezerterów wywodziło się z biednych środowisk robotniczych i chłopskich, często wychowywali się bez jednego lub obojga rodziców. Wcieleni do armii, bez wykształcenia, umiejętności i wiedzy ogólnej, nie uznawali autorytetów. Zapewne ich losy wzbudzały współczucie niektórych przedstawicieli wymiaru sprawiedliwości. Podobny mechanizm zauważyła dziennikarka Monika Piątkowska, która komentując łagodne traktowanie kłusowników w przedwojennych sądach, zauważyła: „przyjezdni inteligenci: leśnicy, sędziowie i urzędnicy postrzegali chłopów jako ofiary systemu historii, stąd wyroki przedwojennych sądów w sprawach o kradzież i kłusownictwo bywały często łagodne" ${ }^{58}$. Stąd też ogłaszanie stosunkowo łagodnych kar, które zdumiewały nie tylko prokuraturę, ale także policjantów i żandarmów, którzy ścigali dezerterów często z narażeniem życia.

Nawet za murami więzienia wielu dezerterów nie porzucało myśli o ponownej ucieczce, choć z pewnością wydostanie się z zakładu karnego było znacznie większym wyzwaniem niż oddalenie się z koszar. W kilku przypadkach odbywający karę dezerterzy uciekli się z więzienia i niemal natychmiast szukali schronienia za granicą. W lipcu 1923 roku z więzienia w Słonimie zbiegł Stefan Malinowski z 26 PU. Przedostał się do ZSRR i tamtejsze władze nakłoniły go do szpiegowskiej misji w Polsce. Nie stało się to od razu, ale po aresztowaniu z powodu bójki. Byłego ułana w kwietniu 1931 roku przerzucono do akcji wywiadowczej w Polsce. W ojczyźnie zatrzymał go patrol KOP ${ }^{59}$.

We wrześniu 1926 roku z wojskowego więzienia śledczego w Wilnie wspólnie zbiegło dwóch skazanych za dezercję żołnierzy. Zostali bardzo szybko złapani ${ }^{60}$. Zatrzymanych oskarżono między innymi o udział w „dezercji zbiorowej”. W czerwcu 1933 roku w Miliczu władze niemieckie zatrzymały Karola Łukasika. Okazało się, że jest on dezerterem zbiegłym z polskiego więzienia po 10 miesiącach odbywania kary. Szer. Łukasik miał niedługo powrócić do 4 PAC, by dokończyć służbę wojskową ${ }^{61}$. Również do Niemiec

${ }^{57}$ Niebieski ptak-dusiciel na dezercji, OWK 01.05.1934, nr 122, s. 1.

${ }_{58}$ M. Piątkowska, Życie przestępcze w przedwojennej Polsce: grandesy, kasiarze, brylanty, Warszawa 2012, s. 176.

${ }^{59}$ Archiwum Straży Granicznej, Korpus Ochrony Pogranicza, Dowództwo Dywizjonu Żandarmerii, Odpis z odpisu doniesienia karnego dot. szpiegostwa i dezercji ułana Stefana Malinowskiego z 26 PU, Post. Ż. Przy 8 baonie KOP „Stołpce”, Stołpce 25.04.1931 r., sygn. 178/110, k. 97.

${ }^{60}$ WBH, Departament Sprawiedliwości (dalej: DS) M.S. Wojsk., Odpis wyroku nr Ko: 541/26 WSO nr III w Wilnie z 17.05.1927 r., sygn. I.300.58.141, s. 2, nlb.

${ }^{61}$ APP, Komenda Powiatowa Policji Państwowej w Krotoszynie, Pismo mjr. [Józefa] Baya, dowódcy 7 DŻ, Poznań 06.09.1933 r., sygn. 12, k 1. 
zbiegł z więzienia w Koronowie we wrześniu 1935 roku dezerter Stanisław Rowiński.

Nie sposób rozstrzygnąć, czy więzienia resocjalizowały dezerterów. Dla wielu odzyskanie wolności oznaczało powrót do znienawidzonej służby wojskowej. Po opuszczeniu więzienia nie wszyscy wracali do macierzystych pułków, niektórzy kontynuowali dawne życie wagabundów, drobnych złodziei. Nie szukali więc wsparcia wśród wojskowych wychowawców, tylko na melinach i w domach publicznych. Jak strz. Jan Faleńczyk z 61 pp, który na początku lutego 1934 roku opuścił więzienie wojskowe w Grudziądzu i nie zgłosił się do macierzystego bydgoskiego pułku. Jak zanotowano w sprawozdaniu PŻ z Bydgoszczy w kwietniu 1934 roku, ,po przybyciu do Bydgoszczy nie zgłosił się w oddziale, lecz przebywał u kobiet lekkich obyczajów i w czasie tym dokonał kradzieży z włamaniem w dwóch wypadkach, a skradzione rzeczy przyniósł do mieszkania prostytutek" ${ }^{\prime 2}$. Po kilku dniach Faleńczyk został zatrzymany przez PŻ i odstawiony do oficera sądowego przy wojskowym sądzie rejonowym w Bydgoszczy.

Do więzienia trafiali również dezerterzy złodzieje, którzy podczas rozpraw sądowych zatajali swoją ucieczkę z wojska. Tak jak w Łodzi w 1932 roku. Do tamtejszego więzienia trafił szer. Antoni Styczenko z 3 komp. 9 pp w Zamościu. Łódzka żandarmeria raportowała: ,podczas pobytu na samowolnym oddaleniu się, przebywał [Antoni Styczenko - R.K.] w ubraniu cywilnym w okolicy Łodzi - przy czym w tym czasie dopuścił się wraz z cyw. Szymańskim Tadeuszem kilku kradzieży. Aresztowany przez policję nie przyznał się, że jest osobą wojskową wskutek czego został przekazany do dyspozycji Sądu Grodzkiego w Łodzi. Wyrokiem wspomnianego sądu został skazany na 6 miesięcy więzienia. Karę odbywał w więzieniu karnym w Łodzi. Po ustaleniu powyższych danych, niezwłocznie powiadomiono Prokuratora przy WSO IV w Łodzi" ${ }^{63}$.

Pobłażliwe traktowanie dezerterów wywoływało, szczególnie w latach 20., nieskrywaną irytację wielu wysokich rangą dowódców WP. W czerwcu 1924 roku ppłk Leopold Cehak, zastępca dowódcy 3 PAL w Zamościu uznał, że sądy wymierzają zbiegom zbyt niskie kary, a także dopuszczają, aby dobrowolnie powracający $z$ dezercji żołnierze odpowiadali przed sądem $\mathrm{z}$ wolnej stopy. W opinii ppłk. Cehaka zachęcało to do ucieczek z wojska zarówno byłych dezerterów, jak i kolejnych żołnierzy ${ }^{64}$ Gen. bryg. Wiktor Jarosz, zastępca dowódcy OK nr X, bez ogródek skomentował niskie wyroki WSO w marcu 1923 roku: „łagodne kary

${ }^{62}$ WBH, Oddział Żandarmerii (dalej: OŻ), Przestępstwa, samobójstwa, nieszczęśliwe wypadki oraz przewinienia dyscyplinarne na terenie OK. VIII. Sprawozdanie PŻ Bydgoszcz za I kwartał 1934 r. z 03.04.1934 r., sygn. I.375.8.28, s. 5., nlb.

${ }^{63}$ WBH, OŻ, Sprawozdanie PŻ Łódź z 19.01.1933 r., sygn. I.375.4.119, s. 4.

${ }^{64}$ WBH, O. II SG WP, Meldunek dowództwa 3 PAL do O. II. Szt.. Gen. DOK II w Lublinie, Zamość, 24.06.1924 r., sygn. I. 303.4.2510, s. 1, nlb. 
za dezercję, kary kilkutygodniowego czy kilkumiesięcznego więzienia nie zawsze skutecznie przeciwdziałają dezercji, przez jednostki zepsute karą aresztu częstokroć przyjmowane jest [to] jako wypoczynek" ${ }^{{ }^{6} 5}$.

Wielu dowódców pułków niezadowolonych z orzekania przez sądy łagodnych kar za dezercję zapominało, że niekiedy pobłażliwość wobec dezerterów zaczynała się w podległych im formacjach, jak choćby w przypadku ułana Aby Sporna, który między listopadem 1927 roku a styczniem 1928 aż trzy razy dopuścił się dezercji, co nie zostało nigdzie zgłoszone ${ }^{66}$. Dopiero po czwartym incydencie został spisany protokół, w którym uwzględniono poprzednie ucieczki.

O tym, że sądownictwo w przedwojennej Polsce traktowało dezerterów bardzo łagodnie, świadczy także otrzymywanie przez dezerterów, na przykład ze względów zdrowotnych, zgody na przerwę w odbywaniu kary. Wnoszono apelacje, nawet w przypadku najcięższych zbrodni, nie tylko o skrócenie wyroków, ale o całkowite uniewinnienie. Być może zachęcały do tego łagodne kary - od 2 do 4 lat więzienia. Strz. Zygmunt Trzciński na początku stycznia 1926 roku samowolnie opuścił 2 pp w Pińczowie, po czym wyjechał do Gródka Jagiellońskiego, tam zastrzelił swoją narzeczoną. Zbiegły żołnierz został skazany na 10 lat więzienia, ale po kilku miesiącach wyrok skrócono o połowę. Skazany nie odbył nawet tego wyroku - wyszedł na wolność już na początku lipca 1928 roku, korzystając z amnestii ogłoszonej 22 czerwca 1928 roku przez prezydenta. Co więcej, w październiku 1929 roku Trzciński wniósł do WSO prośbę o wykreślenie go z ewidencji rejestrów karnych argumentując, że ciążące na nim skutki kary nie pozwalają mu ubiegać się o służbę zawodową w wojsku lub policji ${ }^{67}$.

O przyspieszenie zwolnienia dezerterów z więzień starały się także rodziny. Do Departamentu M.S.Wojsk., WSO i prokuratury wojskowej napływały dziesiątki listów, w których rodzice i żony osadzonych błagały o natychmiastowe wypuszczenie na wolność swoich synów i mężów. W korespondencji przedstawiano tragiczną sytuację finansową rodziny i podkreślano, że skazani są jedynym ratunkiem dla swoich żyjących w biedzie rodziców i dzieci. Zdarzały się relacje zupełnie zmyślone, jak list ojca skazanego Zygmunta Trzcińskiego, Tomasza, w którym opisywał, że nie ma pracy, żyje w skrajnej nędzy, tymczasem wraz $\mathrm{z}$ żoną pracowali w przędzalni ${ }^{68}$.

W nielicznych przypadkach opisywane sytuacje były prawdziwe i prezydent II RP decydował o ułaskawieniu skazanego.

${ }^{65}$ WBH, O. II SG WP, Raport o stanie dezercji O. II. SG WP DOK nr X z 10.03.1923 r., sygn. I. 304.4.2490, s. 2, nlb.

${ }^{66}$ WBH, O. II SGWP, Protokół z 25.01.1928 r., sygn. I.303.4.2511., k. 484.

${ }^{67}$ WBH, DS, Uchwała WSO nr X w Przemyślu, podjęta 30.10.1929 r., sygn. I. 300.58.141., s. 2, nlb.

${ }^{68}$ WBH, DS, Raport szefa Departamentu M.S.Wojsk. i Naczelnego Prokuratora Wojskowego do Prezydenta Rzeczypospolitej z 03.08.1927 r., sygn. I. 300.58.141., s. 2, nlb. 


\title{
DESERTERS BEFORE THE COURT IN THE SECOND POLISH REPUBLIC
}

\begin{abstract}
The military judicial system punished several thousand soldiers for desertion between 1921 and 1939. Among them were not only Poles but also Ukrainians, Belarusians, Jews, Germans and Lithuanians who served in the Polish army. Many of these deserters were judged not only for desertion from the Polish Armed Forces but also for various other criminal offences. The deserters included servicemen from various regiments as well as soldiers from the Border Protection Corps, who stayed abroad for several years. Despite the seriousness of the charges among which were espionage and revealing classified information to intelligence services of foreign countries, the deserters often avoided severe punishment. Such decisions were largely affected by the fact that they were defended in court by renowned attorneys such as colonel dr. Antoni Neusser in Poznan, dr. Leopold Süesser in Cracow, Stanisław Mrozowski and dr. Roman Aleksandrowicz in Lviv as well as Stanisław Rundo in Warsaw. These defence attorneys frequently emphasized the poor financial situation of the deserters' families, difficult childhood of the fugitives and the fact that they were illiterate. Lenient sentences in numerous court cases irritated both the prosecution and the commanders of some regiments. Many deserters showed remorse and pledged genuine change. However, there were also people who remained unchanged by prison. Some of them even escaped incarceration.
\end{abstract}

\section{LES DESERTEURS DEVANT LA JUSTICE DE LA DEUXIEME REPUBLIQUE DE POLOGNE}

\section{Resumé}

Dans les années 1921-1939, la juridiction militaire a puni quelques milliers de soldats qui avaient décidé de déserter. Parmi eux se trouvaient des Polonais, mais aussi des Ukrainiens, des Biélorusses, des Juifs, des Allemands et des Lituaniens servant dans l'armée polonaise. Plusieurs déserteurs ont été jugés non seulement pour la défection, mais aussi pour diverses infractions pénales. Parmi les fugitifs de divers régiments, ainsi que les soldats du Corps de garde-frontières, il y avait des soldats qui avaient passé plusieurs années à l'étranger. Malgré de graves allégations d'espionnage et de transmission d'informations confidentielles aux services secrets des États étrangers, les déserteurs évitaient souvent de lourdes peines. Ces décisions étaient largement influencées par le fait que les déserteurs étaient défendus devant les tribunaux par des avocats éminents. A Poznań, le colonel Dr Antoni Neusser, le Dr Leopold Süesser à Cracovie, Stanisław Mrozowski et le Dr Roman Aleksandrowicz à Lviv et Stanisław Rundo à Varsovie. Les défenseurs soulignaient souvent la mauvaise situation matérielle des familles des déserteurs, l'enfance difficile des fugitifs et l'analphabétisme. Dans de nombreux cas, les peines légères prononcées par les tribunaux irritaient le parquet et aussi les commandants de certains régiments. Beaucoup de déserteurs ont montré leur repentance et désiraient sincèrement une amélioration. Cependant, il y en avait aussi ceux qui n'ont pas été changés par la prison. Certains d'entre eux se sont même évadés de cet endroit. 